\title{
Occurrence of Two Sucrose Synthase Isozymes during Maturation of Japanese Pear Fruit
}

\author{
Akio Suzuki, Yoshinori Kanayama, and Shohei Yamaki \\ Laboratory of Horticultural Science, School of Agricultural Sciences, Nagoya University, Chikusa, \\ Nagoya 464, Japan
}

Additional index words. enzyme purification, fruit ripening, isozyme of sucrose synthase, sucrose metabolism

\begin{abstract}
The properties of sucrose synthase (SS) isozymes partially purified from immature fruit (SS I) of Japanese pear (Pyrus serotina Rehder var. culta Rehder) were different than those of mature fruit (SS II). A clear difference in elusion pattern during DEAE-cellulose chromatography was observed, although the apparent molecular weight of the native proteins extracted from both stages was $350 \mathrm{kD}$. The $\mathrm{Km}$ value of SS II for UDP was similar to that for UDP-glucose; while with SS I, the Km for UDP was lower than that for UDP-glucose. This suggests that SS II activity favors sucrose synthesis compared with SS I, which favors sucrose cleavage. The optimum pH for activity toward sucrose synthesis was 8.0 for SS II and 8.5 to 9.5 for SS I. SS II from mature fruit may be an isozyme of SS occurring during periods of rapid sucrose accumulation, while SS I from immature fruit is more similar to the typical SS which functions mainly toward sucrose cleavage in many plants.
\end{abstract}

The mechanism of sucrose accumulation in fruit varies among species and varieties. In Citrus, some translocated sucrose is hydrolyzed to glucose and fructose by acid invertase (AIV) before entering the fruit where it is resynthesized to sucrose via sucrose phosphate synthase (SPS) rather than sucrose synthase (SS) (Lowell et al., 1989). A similar situation exists in strawberry (Hubbard et al., 1991) and melon fruit, where the sucrose resulting from catabolism of raffinose or stachyose is metabolized similarly before entering the fruit (Hubbard et al., 1989). Also, in many plants that accumulate starch in their storage tissue, SPS is involved in converting starch to sucrose (Hawker, 1971).

However, SS also seems to be involved in sucrose accumulation. Peach fruit accumulate sucrose during maturation, accounting for $>80 \%$ of the total soluble sugar (Moriguchi et al., 1990). Total SS activity increased concomitant with the accumulation of sucrose, whereas SPS activity did not. In Asian pear fruit, sucrose accumulation is correlated with a clear rise in SS and SPS activities during maturation. SS activity contributed more to sucrose accumulation than SPS activity based on the comparison of the correlation between SS activity or SPS activity and sucrose content in fruit (Moriguchi et al., 1992).

Generally, however, SS is thought to function in vivo toward sucrose cleavage (Mass et al., 1990; Nolte and Koch, 1993; Wang et al., 1994). Immature Japanese pear and peach fruit also have higher SS activity than mature fruit despite accumulating less sucrose (Moriguchi et al., 1992, 1990). Thus, perhaps two types of $\mathrm{SS}$, one acting toward sucrose synthesis in mature fruit (SS II) and the other acting toward sucrose cleavage in immature fruit (SS I), function during the development of Japanese pear and peach fruit. Peach SS II was purified, and its properties were compared with those of other plants. Kinetic studies suggested that SS II was inclined toward sucrose synthesis in contrast to the suggested action of SS in many other plant tissues, which was inclined toward sucrose cleavage (Moriguchi and Yamaki, 1988).

Received for publication 6 Nov. 1995. Accepted for publication 7 Mar. 1996. This research was supported in part by grants-in-aid (No. 06304013) from the Ministry of Education, Science and Culture of Japan. We thank Mr. K. Sakakibara (technical official in School of Agricultural Sciences, Nagoya University) for assisting in growing the peach fruit. The cost of publishing this paper was defrayed in part by the payment of page charges. Under postal regulations, this paper therefore must be hereby marked advertisement solely to indicate this fact.
Our objective was to compare properties of SS I and SS II from immature and mature Japanese pear fruit.

\section{Materials and Methods}

Plant materials. Japanese pear fruit (cv. Hosui) were cultivated in the orchard at Nagoya Univ. Immature and mature fruit used for enzyme purification were harvested on 15 June and 5 Sept., respectively. Flesh tissues were excised and stored at $-80^{\circ} \mathrm{C}$.

Extraction and purification of enzyme. All procedures were performed at 0 to $4{ }^{\circ} \mathrm{C}$. Two hundred grams of immature fruit or 1 $\mathrm{kg}$ of mature fruit were homogenized in five or two volumes, respectively, of $0.2 \mathrm{M} \mathrm{K}$-phosphate $(\mathrm{pH} 7.8)$ containing $1 \mathrm{~mm}$

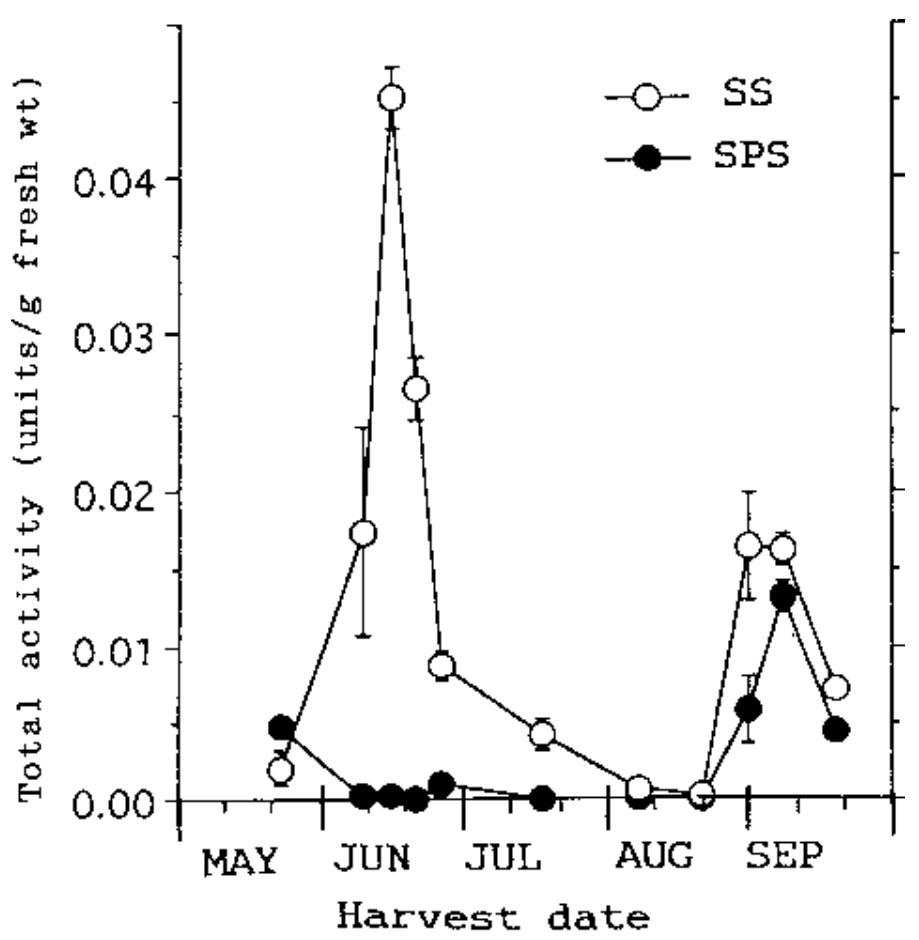

Fig. 1. Seasonal changes in sucrose synthase (SS) and sucrose phosphate synthase (SPS) activities in Japanese pear fruit. SS activity was assayed by assay 1. Each point is the mean \pm SE of three replicates. 
EDTA, $10 \mathrm{~mm} \mathrm{Mg}_{2} \mathrm{SO}_{4}, 10 \mathrm{~mm} \mathrm{Na}$-ascorbate, $2 \mathrm{~mm}$ phenylmethane sulfonyl fluoride (PMSF), $5 \mathrm{~mm} \beta$-mercaptoethanol, $1 \mathrm{~mm}$ dithiothreitol (DTT), and $20 \mathrm{~g}$ of insoluble polyvinylpolypyrrolidone (PVPP). The homogenate was filtered through four layers of gauze and centrifuged at $12,000 \times g$ for $20 \mathrm{~min}$. The supernatant was desalted by passing through a column of Sephadex G-25. The sample was adjusted to $30 \%$ saturation with $\left(\mathrm{NH}_{4}\right)_{2} \mathrm{SO}_{4}$, and centrifuged at $12,000 \times \mathrm{g}$ for $20 \mathrm{~min}$. The supernatant was adjusted to $90 \%$ saturation with $\left(\mathrm{NH}_{4}\right)_{2} \mathrm{SO}_{4}$ and again centrifuged at $12,000 \times \mathrm{g}$ for $30 \mathrm{~min}$. The precipitate was dissolved in a minimal volume of $10 \mathrm{~mm}$ Tris- $\mathrm{HCl}(\mathrm{pH} 8.5)$ containing $0.2 \mathrm{~mm}$ EDTA and $5 \mathrm{~mm} \beta$-mercaptoethanol (buffer A), dialyzed against the same buffer overnight, and applied to a column $\left(2.3 \mathrm{~cm}^{2} \times 13 \mathrm{~cm}\right)$ of DEAE-cellulose (DE-52) that had been equilibrated with buffer A. After the column was washed with buffer A containing $0.08 \mathrm{M} \mathrm{KCl}$, bound proteins were eluted with a $100-\mathrm{ml}$ linear gradient of 0.08 to $0.5 \mathrm{M} \mathrm{KC1}$ in buffer $\mathrm{A}$. The active fractions were pooled, combined with a equal volume of $20 \%$ glycerol and $1 \mathrm{mM}$ PMSF, and concentrated in a collodion bag (Sartorius Co., Tokyo). The sample then was applied to a column $\left(2.8 \mathrm{~cm}^{2} \times 70 \mathrm{~cm}\right)$ of Sepharose 6-B that had been equilibrated in $20 \mathrm{~mm}$ Tris- $\mathrm{HCl}$ buffer ( $\mathrm{pH}$ 7.5) containing $1 \mathrm{~mm}$ EDTA, $2 \mathrm{~mm} \mathrm{Mg}_{2} \mathrm{SO}_{4}, 50 \mathrm{~mm} \mathrm{NaCl}, 5$ mM $\beta$-mercaptoethanol, and $10 \%$ glycerol (buffer D). Proteins

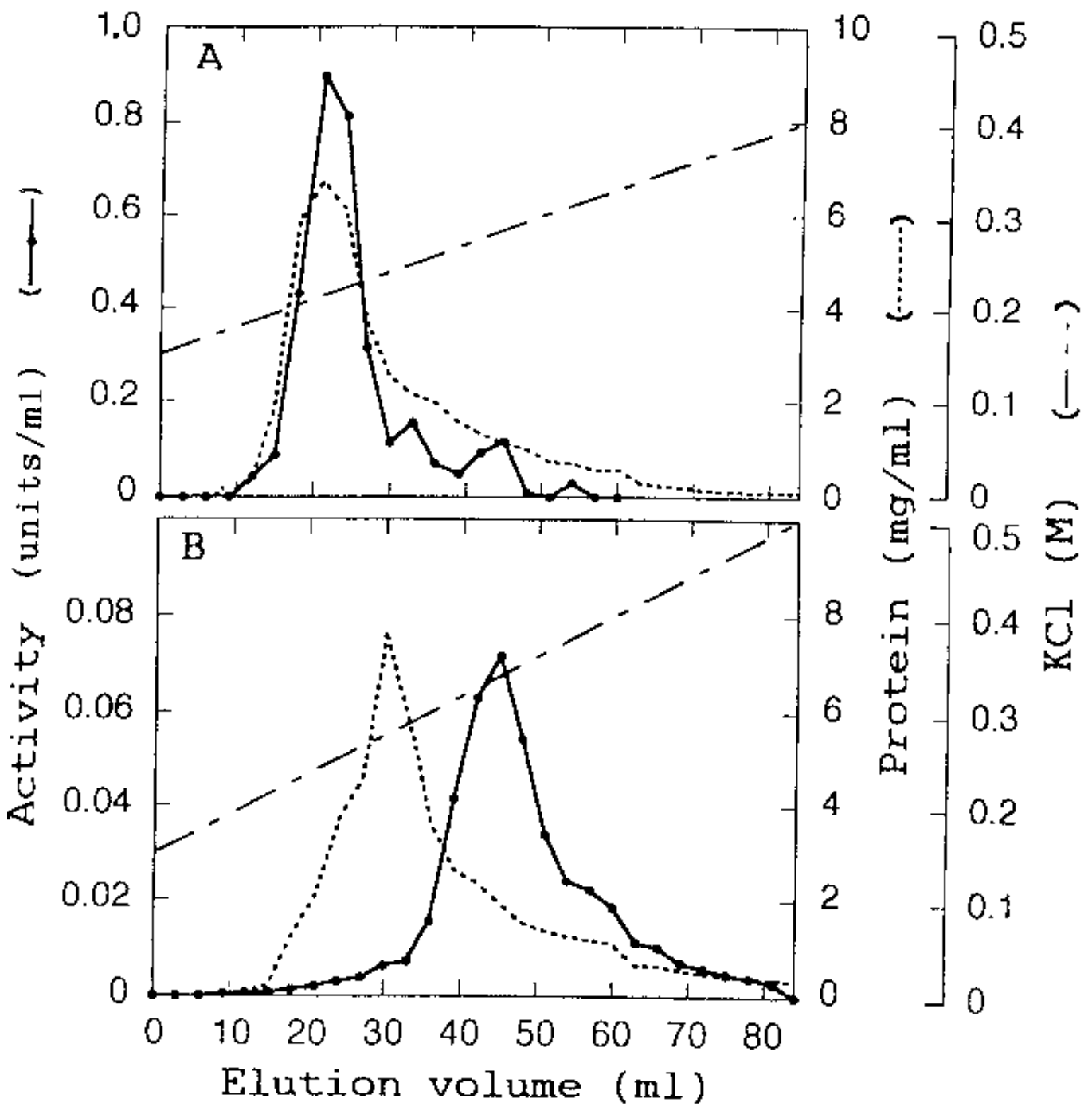

Fig. 2. Elution profiles from DEAE-cellulose (DE-52) column chromatography of sucrose synthase (SS) from (A) immature and (B) mature fruit. Fractions of $3 \mathrm{ml}$ were collected. SS activity was assayed using assay 1. then were eluted with the same buffer. The active fractions were pooled and dialyzed against saturated $\left(\mathrm{NH}_{4}\right)_{2} \mathrm{SO}_{4}$ containing 20 mM Tris, 1 mм EDTA, and $5 \mathrm{~mm} \beta$-mercaptoethanol and then were centrifuged at $35,000 \times \mathrm{g}$ for $30 \mathrm{~min}$. The precipitate was dissolved in $1 \mathrm{ml} 10 \mathrm{~mm}$ HEPES-NaOH (pH 7.5) containing $2 \mathrm{mM} \mathrm{MgC1}_{2}$ and 2 mM DTT (buffer C) and was desalted using a NAP-10 column (Pharmacia Biotech, Uppsala, Sweden). The sample was subjected to affinity chromatography on a column $\left(0.5 \mathrm{~cm}^{2} \times 10 \mathrm{~cm}\right)$ of UDPGlcUA-agarose (Sigma Chem Co., St. Louis) equilibrated in buffer $\mathrm{E}$. The column then was washed with $15 \mathrm{ml}$ of buffer $\mathrm{E}$, and the enzyme was eluted with $15 \mathrm{ml}$ of buffer E containing $0.2 \mathrm{M} \mathrm{KC} 1$ at a flow of $0.05 \mathrm{ml} \cdot \mathrm{min}^{-1}$. The active fraction was collected and used as a partially purified SS fraction.

Assay of SS activity. Sucrose produced by the reaction in assay 1 (for sucrose synthesis) was determined by Roe's method (Roe, 1934). UDP produced from assay 2 (for sucrose synthesis) was determined by the coupled enzyme method modified by Morell and Copeland (1985). Fructose produced by the reaction in assay 3 (for sucrose cleavage) was determined by the Nelson-Somogyi method (Nelson, 1944). UDPG produced from assay 4 (for sucrose cleavage) was determined by the coupled enzyme method modified by Morell and Copeland (1985). Details of all four assay methods were described previously (Moriguchi and Yamaki, 1988).

SPS activity was measured using assay 1 , except that $15 \mathrm{~mm}$ fructose-6-phosphate was used in place of $15 \mathrm{~mm}$ fructose and 1.3 $\mathrm{mm} \mathrm{NaF}$ was added to the reaction tubes. One unit of activity was defined as the amount of enzyme that catalyzed the formation of $1 \mu \mathrm{mol}$ product $/ \mathrm{min}$.

Protein assay. Protein was determined by the Bradford (1976) method using BSA as a standard.

Determination of relative molecularmass by gelfiltration chromatography. Sepharose 6-B chromatographic conditions were the same as those previously described for purification of the enzyme. Thyroglobulin (MW: $669,000)$, apoferritin $(443,000)$, $\beta$-amylase $(200,000)$, alcohol dehydrogenase $(150,000)$, and BSA $(66,000)$ were used as calibration proteins.

\section{Results}

Changes in SS and SPS activities during fruit development. Total SS activity rose rapidly in early June to reach a maximum on 14 June (Fig.l). Thereafter, total activity decreased until 28 Aug. when it increased again. Thus, two peaks of extractable activity were evident, one in immature and one in mature fruit. However, SPS activity remained at a low level until the mature stage and rose simultaneously 
with the rise in SS activity beginning 28 Aug. and reaching a maximum 4 Sept.

Partial purification of SS I and SS II. DEAE-cellulose chromatography revealed two SS isozymes (Fig. 2). Chromatography of the extract from mature fruit showed a relatively large peak of activity at $0.34 \mathrm{M} \mathrm{KC1} \mathrm{(SS} \mathrm{II)}$ (Fig. 2B), whereas SS I, which eluted at $0.21 \mathrm{M} \mathrm{KC1} \mathrm{(Fig.} \mathrm{2A),}$ was predominant in immature fruit. This finding suggests that the SS I and SS II isozymes have different isoelectric points. The active fractions of the main peaks were pooled and applied to the Sepharose 6-B gel filtration column. The elusion volumes of the two SS isozymes was the same, suggesting the native proteins are of a similar size (data not shown).

During UDPGlcUA-agarose affinity chromatography, a difference in elusion pattern between SS I and SS II was evident (Fig. 3). Almost all of the SS II activity eluted with buffer containing no $\mathrm{KC} 1$, while SS I eluted mainly in buffer containing $0.2 \mathrm{M} \mathrm{KC1}$. The pooled main peaks of SS II and SS I after affinity chromatography were designated as partially purified SS I and II. Through the previously explained procedures, SS I and II were partially purified to the final activities of 6.67 and 0.56 unit/mg protein, respectively (Table 1). The apparent molecular weight of SS I and young SS II was estimated at 350,000 by Sepharose 6-B gel chromatography (data not shown).

pH optimum. The optimum $\mathrm{pH}$ of sucrose synthesis for SS II was 8.0, different from the 9.0 for SS I (Fig. 4). Both activities decreased rapidly at lower $\mathrm{pH}$. The optimum $\mathrm{pH}$ for sucrose cleavage of SS I and II were 7.0 and 7.5, respectively, but the activities fell off sharply at higher and lower $\mathrm{pH}$ ranges.

Kinetics. With SS II, the sucrose cleavage reaction conformed roughly to Michaelis-Menten kinetics (data not shown); the kinetic characteristics are summarized in Table 2. The Km value for fructose $(16.7 \mathrm{~mm})$ was somewhat lower than that for sucrose (43.6 $\mathrm{mm})$. The affinity of the enzyme for UDPG $(\mathrm{Km}=0.06 \mathrm{~mm})$ was similar to that of UDP $(\mathrm{Km}=0.05 \mathrm{~mm})$. No significant differences in Vmax existed between reactions toward sucrose synthesis and cleavage.

With SS I, sucrose synthesis and cleavage also followed Michaelis-Menten kinetics (data not shown). The $\mathrm{Km}$ value for sucrose (21.4 mM) was lower than that for SS II (43.6 mM). Moreover, the affinity of the enzyme for UDP $(\mathrm{Km}=0.03 \mathrm{~mm})$ was substantially greater than that for UDPG $(\mathrm{Km}=0.27 \mathrm{~mm})$. The Vmax toward sucrose synthesis was higher than that toward sucrose cleavage.
Table 1. Partial purification of sucrose synthase (SS) from immature and mature fruit of Japanese pear. SS activity was assayed using assay 1.

\begin{tabular}{|c|c|c|c|c|}
\hline $\begin{array}{l}\text { Purification } \\
\text { steps }\end{array}$ & $\begin{array}{l}\text { Total act. } \\
\text { (unit) }\end{array}$ & $\begin{array}{l}\text { Protein } \\
(\mathrm{mg})\end{array}$ & $\begin{array}{c}\text { Specific act. } \\
\text { (unit/mg) }\end{array}$ & $\begin{array}{c}\text { Yield } \\
(\%)\end{array}$ \\
\hline \multicolumn{5}{|c|}{ Immature SS (SS I) } \\
\hline Crude extract & 16.3 & 390 & 0.042 & 100 \\
\hline $0 \%$ to $90 \%\left(\mathrm{NH}_{4}\right)_{2} \mathrm{SO}_{4}$ & 10.9 & 207 & 0.053 & 66.9 \\
\hline DEAE-cellulose (SS I) & 5.0 & 60.7 & 0.082 & 30.7 \\
\hline Sepharose-6B & 3.6 & 6.70 & 0.537 & 22.1 \\
\hline UDPGlcUA-agarose & 1.0 & 0.15 & 6.67 & 6.1 \\
\hline \multicolumn{5}{|c|}{ Mature SS (SS II) } \\
\hline Crude extract & 5.3 & 448 & 0.012 & 100 \\
\hline $30 \%$ to $90 \%\left(\mathrm{NH}_{4}\right)_{2} \mathrm{SO}_{4}$ & 2.5 & 458 & 0.010 & 47.2 \\
\hline DEAE-cellulose (SS II) & 1.6 & 33.7 & 0.048 & 30.2 \\
\hline Sepharose-6B & 1.4 & 5.54 & 0.253 & 26.4 \\
\hline UDPGlcUA-agarose & 0.2 & 0.36 & 0.556 & 3.8 \\
\hline
\end{tabular}



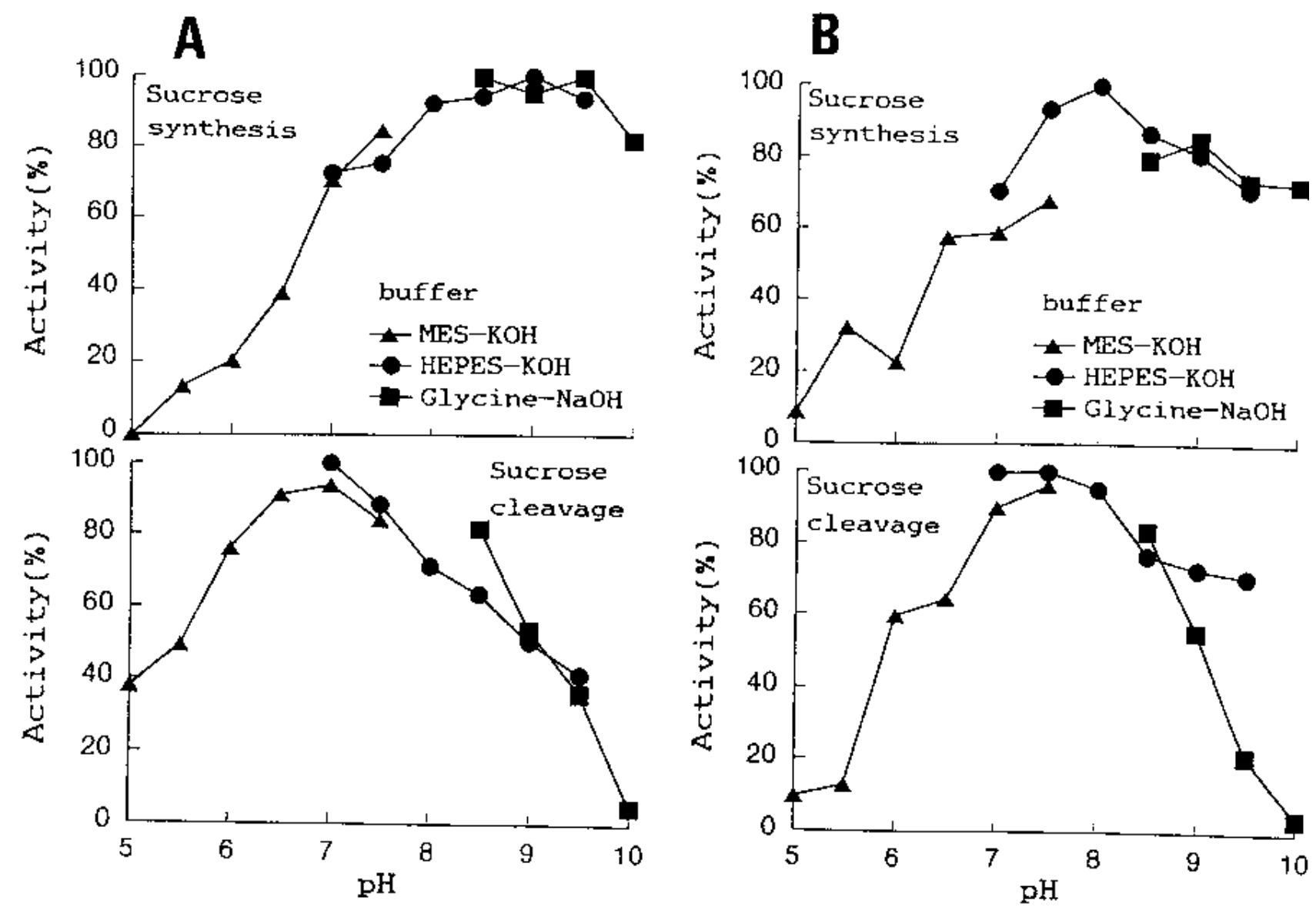

Fig. 4. pH dependency of (A) immature fruit (SS I) and (B) mature fruit (SS II) activity. Synthesis and cleavage of sucrose were assayed by assays 1 and 3, respectively.

\section{Discussion}

SS II had a Km value for UDP similar to that of UDPG, while with SS I, the Km value for UDP was lower than that of UDPG. Moreover, the Km value for UDPG was lower for SS II than that for SS I but vice versa for UDP. The optimum pH for sucrose synthesis by SS II and I was 8.0 and 9.0, respectively. The optimum $\mathrm{pH}$ of activity toward sucrose cleavage was 7.5 and 7.0 for SS II and I, respectively. In Table 3, Km values for SS from various species and tissues are listed. The Km values for UDP were lower than for UDPG in many plant species, except that of mature peach fruit (Moriguchi and Yamaki, 1988) and tapioca root (Shukla and Sanwal, 1971). This result suggests that the in vivo activity of SS generally is toward the direction of sucrose cleavage rather than sucrose synthesis. Moreover, the optimum $\mathrm{pH}$ of many SS activities were in a range of 8 to 9 for sucrose synthesis and 6 to 7 for sucrose cleavage. Thus, the SS I isozyme from immature Japanese pear fruit is similar to the typical type of SS in many other plant species and tissues.

However, SS II had an equal affinity for UDP and UDPG and, therefore, could potentially be involved in sucrose cleavage and synthesis in vivo. SS from mature peach fruit or tapioca root did not show much disparity in Km values for UDP and UDPG (Moriguchi and Yamaki, 1988; Shukla and Sanwal, 1971) and had a pH optimum near neutrality for sucrose synthesis and cleavage. Thus, the SS II in our study is similar in properties to these SSs and is of a somewhat rare type. In cucumber peduncle and fruit, the presence of two SS isozymes that eluted at 0.1 and $0.18 \mathrm{M} \mathrm{KC} 1$ from DEAEcellulose chromatography already was reported (Gross and Pharr, 1982). Furthermore, SS isozymes were found in maize (Echt and tissues was (respectively) 105 (UDPG) and $73 \mu \mathrm{M}$ (UDP) in the phloem exudate of caster bean cotyledons during sucrose synthesis (Geigenberger et al., 1993), 157 and $8.8 \mu \mathrm{m}$ in potato tubers, 262 and $15 \mu \mathrm{M}$ in Ricinus cotyledons, and 88 and $4.3 \mu \mathrm{M}$ in Chenopodium cells (Geigenberger and Stitt, 1993). SS II is considered to react toward either sucrose synthesis or cleavage depending on the balance of UDP-UDPG or sucrose-fructose in vivo as shown by Geigenberger and Stitt (1993). During fruit maturation, it seems that this isozyme could easily function toward sucrose synthesis due to the higher apparent concentration of UDPG relative to the $\mathrm{Km}$ for UDPG and the apparent lower concentration of UDP relative to the $\mathrm{Km}$ for UDP in SS II.

Immature pear fruit just began to actively accumulate starch (Yamaki et al., 1979a) and net cell wall polysaccharides (Yamaki et al., 1979b) in early June, at a time when total SS activity began to increase. This accumulation indicated that a portion of the imported sucrose was metabolized by SS. In general, the biosynthesis of starch and cell wall polysaccharides require ADPG and UDPG, respectively. We expect that SS would supply UDPG (ADPG); in fact, the prominent role of SS was reported in immature fruit of tomato accumulating starch (Wang et al., 1994), vesicular bundles of Citrus fruit (Nolte and Koch, 1993), and protoplasts of maize actively synthesizing cell wall polysaccharides (Mass et al., 1990). Thus, one of the roles of SS I in pear fruit could be to supply the UDPG (ADPG) necessary for synthesis of starch and cell wall polysaccharides.

Although many fruit accumulate sucrose during fruit maturation, to our knowledge, the increase in total SS activity during sucrose accumulation with fruit maturation was reported only for peach and Japanese pear fruit, both members of the Rosaceae 
Chourey, 1985), Sorghum (Chourey et al. 1991), and rice grain (Chan et al., 1990). However, the properties of these SS isozymes were unlike the properties of the SS II isozyme in our paper.

In the Rosaceae family, some sucrose is translocated into fruit from leaves, although the main translocated sugar is sorbitol. Regarding the physiological function of SS II, there was a positive correlation between sucrose accumulation and activity in various varieties of Japanese pear (Moriguchi et al., 1992). Therefore, it was suggested that SS II played an important role in sucrose synthesis. If this is, in fact, the case, a significant supply of UDPG would be expected since the activity of UDPG-pyrophosphorylase toward UDPG synthesis increased with total SS activity during maturation of peach fruit (Moriguchi et al., 1991). Furthermore, the affinity of SS II for UDPG was higher than that of SS I (Table 2) and comparably higher than that from other plant materials (Table 3). Although the content of UDPG and UDP in Japanese pear fruit was not studied, the content of UDPG and UDP in other

Table 2. Kinetic characteristics of sucrose synthase (SS) from Japanese pear fruit. Assays 2 and 3 were used to assay the reaction for sucrose synthesis and sucrose cleavage, respectively. The replicate is shown in the parentheses.

\begin{tabular}{lcccc}
\hline \hline & \multicolumn{2}{c}{ Substrate } & & \multicolumn{1}{c}{$\begin{array}{c}\text { Vmax } \\
\text { (unit/ }\end{array}$} \\
\cline { 2 - 3 } Variable & $\begin{array}{c}\text { First } \\
\text { (varied concn) }\end{array}$ & $\begin{array}{c}\text { Second } \\
\text { (fixed concn) }\end{array}$ & $\begin{array}{c}\text { Km } \\
(\mathrm{mM})\end{array}$ & $\begin{array}{c}\text { mg protein) } \\
\text { ms I }\end{array}$ \\
\hline SS $^{\mathrm{z}}$ & Fructose & UDPG & $10.1(6.6)$ & 12.8 \\
& UDPG & Fructose & $0.27(0.31)$ & 12.4 \\
& Sucrose & UDP & $21.4(35.0)$ & 3.7 \\
& UDP & Sucrose & $0.03(0.03)$ & 3.7 \\
SS II $^{\mathrm{z}}$ & Fructose & UDPG & $16.7(27.6)$ & $0.5(0.5)$ \\
& UDPG & Fructose & $0.06(0.07)$ & $0.5(0.4)$ \\
& Sucrose & UDP & $43.6(65.0)$ & $0.5(0.4)$ \\
& UDP & Sucrose & $0.05(0.07)$ & $0.5(0.5)$ \\
\hline
\end{tabular}

${ }^{\mathrm{Z}}$ Immature (SS I) or mature (SS II) fruit.

Table 3. Km values of the reaction toward sucrose synthesis and cleavage on sucrose synthase from various plant species. Only the references involving the kinetic characteristics of all four substrates are listed.

\begin{tabular}{|c|c|c|c|c|}
\hline \multirow{2}{*}{$\begin{array}{l}\text { Plant } \\
\text { species }\end{array}$} & \multicolumn{4}{|c|}{ Substrate $(\mathrm{mM})$} \\
\hline & Fructose & Sucrose & UDPG & UDP \\
\hline $\begin{array}{l}\text { Soybean nodule } \\
\text { (Morell and Copeland, 1985) }\end{array}$ & 3.7 & 31 & 0.012 & 0.005 \\
\hline $\begin{array}{l}\text { Immature tomato fruit } \\
\text { (Sun et al. 1992) }\end{array}$ & 8.4 & 53 & 0.088 & 0.019 \\
\hline $\begin{array}{l}\text { Tapioca tuber } \\
\text { (Shukla and Sanwal, 1971) }\end{array}$ & 2.6 & 10 & 8.3 & 6.6 \\
\hline $\begin{array}{l}\text { Maize endosperm } \\
\text { (Tsai, 1974) }\end{array}$ & 2.1 & 40 & 1.14 & 0.14 \\
\hline Rice & & & & \\
\hline $\begin{array}{l}\text { Ripening grain } \\
\text { (Nomura and Akazawa, 1973) }\end{array}$ & 6.9 & 290 & 5.3 & 0.8 \\
\hline $\begin{array}{l}\text { Mid-milky grain } \\
\text { (Murata, 1972) }\end{array}$ & 2.9 & 30 & 2.7 & 0.11 \\
\hline $\begin{array}{l}\text { Potato tuber } \\
\text { (Murata, 1972) }\end{array}$ & 1.4 & 55 & 2.0 & 0.14 \\
\hline $\begin{array}{l}\text { Sweetpotato root } \\
\text { (Murata, 1971) }\end{array}$ & 1.0 & 31 & 0.71 & 0.13 \\
\hline $\begin{array}{l}\text { Jerusalem artichoke tuber } \\
\text { (Avigad, 1964) }\end{array}$ & 1.6 & 33 & 0.64 & 0.32 \\
\hline $\begin{array}{l}\text { Mature peach fruit } \\
\text { (Moriguchi and Yamaki, 1988) }\end{array}$ & 4.8 & 63 & 0.033 & 0.08 \\
\hline
\end{tabular}

family. The role of other SS isozymes in these species remains to be elucidated.

\section{Literature Cited}

Avigad, G. 1964. Sucrose-uridine diphosphate glucosyltrans ferase from Jerusalem artichoke tubers. J. Biol. Chem. 239:3613-3618.

Bradford, M.M. 1976. A rapid and sensitive method for the quantitation of microgram quantities of protein utilizing the principle of protein-dye binding. Anal. Biochem. 72:248-254.

Chan, H.Y., T.Y. Ling, R.H. Juang, I.N. Ting, H.Y. Sung, and J.C. Su. 1990. Sucrose synthase in rice plants. Growth associated changes in tissue specific distributions. Plant Physiol. 94:1456-1461.

Chourey, P.S., E.W. Taliercio, and E.J. Kane. 1991. Tissue specific expression and anaerobically induced posttrans criptional modulation of sucrose synthase genes in Sorghum bicolor M. Plant Physiol. 96:485-490.

Echt, C.S. and P.S. Chourey. 1985. A comparison of two sucrose synthetase isozymes from normal and shrunken-1 maize. Plant Physiol. 79:530-536.

Geigenberger, P., S. Langenberger, I. Wilke, D. Heineke, H.W. Heldt, and M. Stitt. 1993. Sucrose is metabolised by sucrose synthase and glycolysis within the phloem complex of Ricinus communis L. seedlings. Planta 190:446-453.

Geigenberger, P. and M. Stitt. 1993. Sucrose synthase catalyses a readily reversible reaction in vivo in developing potato tubers and other plant tissues. Planta 189:329-339.

Gross, K.C. and D.M. Pharr. 1982. Cucumber fruit sucrose synthase isozymes. Phytochemistry 21:1241-1244.

Hawker, J.S. 1971. Enzymes concerned with sucrose synthesis and transformations in seeds of maize, broad bean and caster bean. Phytochemistry 10:2313-2322.

Hubbard, N.L., S.C. Huber, and D.M. Pharr. 1989. Sucrose phosphate synthase and acid invertase as determinants of sucrose concentration in developing muskmelon (Cucumis melo L.) fruits. Plant Physiol. 91:1572-1534.

Hubbard, N.L., D.M. Pharr, and S.C. Huber. 1991. Sucrose phosphate synthase and other sucrose metabolizing enzymes in fruits of various species. Physiol. Plant. 82:191-196.

Lowell, C.A., P.T. Tomlinson, and K.E. Koch. 1989. Sucrose metabolizing enzymes in transport tissues and adjacent sink structures in developing citrus fruit. Plant Physiol. 90:1394-1402.

Mass, C., S. Schaal, and W. Werr. 1990. A feedback control element near the transcription start site of the maize shrunken gene determines promoter activity. EMBO J. 9:3447-3452.

Morell, M. and L. Copeland. 1985. Sucrose synthase of soybean nodules. Plant Physiol. 78:149-154.

Moriguchi, T., K. Abe, T. Sanada, and S. Yamaki. 1992. Levels and role of sucrose synthase, sucrose-phosphate synthase and acid invertase in sucrose accumulation in fruit of Asian pear. J. Amer. Soc. Hort. Sci. 117:274-278.

Moriguchi, T., Y. Ishizawa, T. Sanada, S. Teramoto, and S. Yamaki. 1991. Role of sucrose synthase and other related enzymes in sucrose accumulation in peach fruit. J. Jpn. Soc. Hort. Sci. 60:531-538.

Moriguchi, T., T. Sanada, and S. Yamaki. 1990. Seasonal fluctuations of some enzymes relating to sucrose and sorbitol metabolism in peach fruit. J. Amer. Soc. Hort. Sci. 115:278-281.

Moriguchi, T. and S. Yamaki. 1988. Purification and characterization of sucrose synthase from peach (Prunus persica) fruit. Plant Cell Physiol. 29:1361-1366.

Murata, T. 1971. Sucrose synthetase of sweet potato roots. Part II. A kinetic study. Agr. Biol. Chem. 35:1441-1448.

Murata, T. 1972. Sucrose synthetase of rice grains and potato tubers. Agr. Biol. Chem. 36:1815-1818.

Nelson, N. 1944. A photometric adaptation of the Somogyi method for the determination of glucose. J. Biol. Chem. 153:375-380.

Nolte, K.D. and K.E. Koch. 1993. Companion-cell specific localization of sucrose synthase in zones of phloem loading and unloading. Plant Physiol. 101:899-905.

Nomura, T. and T. Akazawa. 1973. Enzymic mechanism of starch synthesis in ripening rice grains. VII. Purification and enzymic properties of sucrose synthetase. Arch. Biochem. Biophys. 156:644-652.

Roe, J.H. 1934. A colorimetric method for the determination of fructose in blood and urine. J. Biol. Chem. 107:15-22.

Shukla, R.N. and G.G. Sanwal. 1971. Studies on UDP-glucose: D- fructose 2glucosyltransferase from tapioca tuber. Arch. Biochem. Biophys. 142:303-309.

Sun, J., T. Loboda, S.-J.S. Sung, and C.C. Black, Jr. 1992. Sucrose synthase in wild tomato, Lycopersicon chmielewskii, and tomato fruit sink strength. Plant Physiol. 98:1163-1169.

Tsai, C.Y. 1974. Sucrose-UDP glucosyltransferase of Zea mays endosperm. Phytochemistry 13:885-891.

Wang, F., A.G. Smith, and M.L. Brenner. 1994. Temporal and spatial expression pattern of sucrose synthase during tomato fruit development. Plant Physiol. 104:535-540. Yamaki, S., I. Kajiura, and N. Kakiuchi. 1979a. Changes in sugars and their related enzymes during development and ripening of Japanese pear fruit (Pyrus serotina Rehder var. culta Rehder). Bul. Fruit Tree Res. Sta. A6:15-26.

Yamaki, S., Y. Machida, and N. Kakiuchi. 1979b. Changes in cell wall polysaccharides and monosaccharides during development and ripening of Japanese pear fruit. Plant Cell Physiol. 20:311-321. 